\title{
Qualitative Comparative Analysis of Codes of Ethics of Companies in the Czech Republic Operating Nationally or Internationally
}

\author{
Zdeněk Caha ${ }^{1, *}$, Michaela Ruso ${ }^{1}$, and Michaela Procházková ${ }^{1}$ \\ ${ }^{1}$ Institute of Technology and Business in České Budějovice, Faculty of Corporate Strategy, Okružní \\ 517/10, 37001 České Budějovice, Czech Republic
}

\begin{abstract}
.
Research background: Ethical conduct is considered a pillar of strength within the context of corporate social responsibility. The basic tool for achieving this is a code of ethics, which should form the basis for the ethical management of any company. Globalisation and internationalisation have brought with them the need to have a high-quality code of ethics in place, one that is balanced in terms of content.

Purpose of the article: The aim of the research presented in this contribution is to determine, by means of qualitative comparative analysis, to what extent codes of ethics meet key preconditions for efficacy.

Methods: The analysis was carried out on a sample set of 40 companies from various industrial sectors, and of various size, ownership structure and origin. All the companies were active in the Czech Republic at the time. The main preconditions for determining the efficacy of a code of ethics, and which therefore formed the basis for the qualitative comparative analysis, were set in advance.

Findings \& Value added: The results of the analysis revealed that significant differences exist between companies with national and international spheres of activity with regards to the content and form of their codes of ethics. As a consequence, the preconditions for efficacy were judged not to have been fully met. The primary reason for the differences was the level of importance managements and owners of companies assign to a code of ethics and the emphasis they place on adherence to the provisions set forth in them.
\end{abstract}

Keywords: globalization; CSR; code of ethics; comparative analysis; preconditions for efficacy

JEL Classification: $M 14 ; D 23 ; L 26 ; M 12 ; D 22$

${ }^{*}$ Corresponding author: caha@mail.vstecb.cz 


\section{Introduction}

In today's globalising world, the role of a code of ethics as a tool for the ethical management of a company is growing. Codes of ethics are also considered a practical tool in terms of corporate social responsibility, i.e. how a company maintains and regulates its behaviour towards its stakeholders (e.g. employees) and vice versa, and also therefore for the creation of a socially responsible social culture. Globalisation and internationalisation have brought with them the need to have a high-quality code of ethics in place, in particular one that is balanced in terms of content [1-4]. According to Berenbeim [5], the globalisation of markets is one of the crucial reasons why companies continuously adopt codes of ethics and update the content thereof in compliance with the continuously changing internal and external business environments.

The high level of research interest in codes of ethics around the world is reflected in the hundreds of studies that have been published over the past three decades, of which most focus on the issue of content. Studies that specifically deal with the implementation and efficacy of codes of ethics appear much more rarely [1,3,6]. The period 1992 to 2003 saw a rapid expansion of the use and contents of codes of ethics, which shows that this is an evolving issue, one that is adapting and changing during the course of time. According to Stevens [7], the rapid growth in the number of companies adopting codes of ethics over the previous 20 years could be attributed to the Watergate scandal and anti-corruption laws abroad. According to Singh [8], another change occurred in 2003, when codes of ethics started to deal with the leading role companies play in protecting the environment, as well as adherence to and the fulfilment of their legal responsibilities, as reflected in procedures and sanctions. Kaptein [3] and Adams et al. [9] point out that it is not sufficient for companies only to adopt codes of ethics, thereby identifying a direct relationship between the number of the measures taken and established unethical behaviour. According to Erwin [2], numerous factors exist that might influence the quality of the content of codes of ethics and their consequent implementation. Nevertheless, although he admits that many codes of ethics might contain similar provisions in relation to legal matters, it is very important that the values and visions of a particular company should always be specific to it $[10,11]$. Forster et al. [10] found out that this is not the case for numerous companies). Hoover and Pepper [12] also point out the importance of the use of comprehensible language in codes of ethics and their availability online. Their study showed that companies with a comprehensible code of ethics that is available online are generally held in greater regard and are perceived as being more credible. Garzía-Sanchez [13], KPMG [11] and Benson [14] state that codes of ethics primarily deal with a company's responsibility for the quality of its products and services, adherence to laws and regulations, personal data protection, conflicts of interest, and protection of the environment. Schwartz [15] states that the establishment of a company's basic moral values is the first important step towards the creation of a code of ethics. Egels-Zandén and Lindholm [16] both claim that in general, codes of ethics improve the rights of employees. However, they add that very few highquality research studies exist that confirm this in a demonstrable way. Bartley and EgelsZandén [17] examined in what way and under what terms labour conditions are defined in manufacturing companies that have yet to put a code of ethics in place. They discovered that the rights of employees are most often breached in such companies. This is also demonstrated by $\mathrm{Yu}$ [18], who claims that companies without codes of ethics are more inclined to breach human and labour rights. In his analysis of the contents of codes of ethics, Kaptein [19] found that $67 \%$ of companies emphasize their responsibility for the quality of their products and services, 57\% adherence to regulations, and 56\% environmental protection. A substantial part of the codes he analysed contained sections on the principles underlying the management of relations with stakeholders, the appropriate 
behaviour of employees, the basic values of a company, or on the handling of company assets. Kaptein's research also revealed that only $52 \%$ of companies monitor adherence to the principles set out in such documents. Remišová and Winkler [20] focus on the differences between the codes of ethics of companies in Slovakia and West Germany. They found that the codes of ethics of Slovak companies are more focused on ethical issues, which reflects the greater incidence of ethical problems, while those of German companies more often focus on global matters and environmental protection.

As yet, not many studies dealing with codes of ethics have been published in the Czech Republic. Among the older studies worthy of mention, which examine the existence of codes of ethics, are those by Džbánková [21] and Transparency International - Czech Republic (2006, 2013 and 2015), and among the more recent studies, that of Pricewaterhousecoopers [22] and Caha [23]. The contents of codes of ethics are examined by Pirožek et al. [24], who look at to what extent in Czech branches of multinational companies this is influenced by their mother companies. They concluded that the existence of a code of ethics was more frequent among multinational companies, that these reflected the cultural influences of the mother companies, and that those companies with a code of ethics in place were slightly more economically successful. In their pilot study, Maňák et al. [4] analysed the form, content and structure of the codes of ethics of 20 companies operating in the Czech Republic. KPMG [11] conducted a similar analysis involving 200 of the biggest companies operating in the Czech Republic. The authors found that the codes of ethics differ significantly in terms of their extent, content and quality. The analysed codes very often placed emphasis on conflicts of interest, legal issues, personal data protection and various aspects of CSR. Those of multinational corporations often dealt with crossborder anti-corruption legislation, particularly British and American legislation. According to the study, the fact that some important topics, examples, sanctions, and measures for the protection of whistle-blowers are missing, are basic weak points in the analysed codes of ethics. These findings severely undermine the assumption that codes of ethics can be truly effective. Within this context, the key preconditions for the creation, implementation and evaluation of codes of ethics by companies is dealt with in detail by Remišová [25] and Caha and Urban [26].

\section{Research methodology}

The main goal of the research was to determine by means of qualitative comparative analysis to what extent the contents of codes of ethics of companies operating in the Czech Republic meet key preconditions for efficacy. A partial goal was to determine whether differences exist between those companies operating nationally or internationally.

In accordance with the goal, a sample set of 40 codes of ethics was collated from online sources from companies operating in the Czech Republic. The search was carried out in April 2000 using the google.cz and seznam.cz search engines. The key words used were "code of ethics". This led to a random selection of 40 codes of ethics from companies operating in various industrial sectors, and of various size, ownership structure and origin. We also tried to find whether an English mutation of the code exists.

\subsection{Structure of the codes of ethics in the sample set}

The companies whose codes of ethics were included in the sample set were broken down according to:

a) number of employees: $10 \%$ micro companies, $12.5 \%$ small companies, $22 \%$ mediumsized companies, and 55\% large companies.

b) sphere of activity: $67.5 \%$ of companies operate internationally, and $32.5 \%$ nationally. 
c) industrial sector: $32.5 \%$ are active in the tertiary sector, $63.75 \%$ in the secondary sector, and $3.75 \%$ in the primary sector.

d) availability of an English version: $57.5 \%$ companies did, and $42.5 \%$ did not.

In the subsequent phase of the research, codes of ethics were evaluated according to predefined criteria, which were partly based on the results of previous research $[1,2,8,11,12,15,19,24]$. However, the criteria were modified according to the aim of the research, which was to determine to what extent the codes of ethics of companies operating in the CR meet key preconditions for efficacy $[19,25,26]$. After defining the basic assessment criteria, a standard table was prepared, which contained, in addition to the selected areas of assessment, an assessment scale with regards to how well a particular code of ethics meets the given criterion, i.e. in full, partly, or not at all. The assessment was carried out independently by three assessors, who always marked the relevant sections in the text of the individual codes of ethics. The results were then compared and possible differences verified on the basis of a reassessment of the content. A collective assessment table was then drawn up for all the analysed codes and a quantitative and qualitative summary of the analysis results prepared. A comparison of the codes of ethics for companies operating nationally and internationally was then carried out in compliance with the partial goal.

\section{Results}

The 40 examined codes of ethics vary in terms of length from just a single page up to 72 pages, whereby the median is 4 pages. Almost all are written in comprehensible language (95\% were assessed as fully comprehensible, $5 \%$ as partly comprehensible). Vague formulations only represented a problem in a limited number of cases. The styles used for the formulation of the codes were the personal style (45\%), impersonal style (42\%), and mixed style (13\%). The codes are most frequently divided according to themes, very rarely according to values. Up to $70 \%$ of the codes miss a clear commitment from management to adhere to the code of ethics, either in the form of an introductory or closing paragraph.

Summary of the main findings of the comparative analysis (see Table 1 for details):

- Codes of ethics are primarily (in $80 \%$ of cases) used as a means to appeal for adherence to regulations. However, companies mostly do not go beyond the scope of the law when making such provisions.

- Codes of ethics emphasize what is and is not appropriate employee behaviour, including issues such as corruption and bribery (equally in $77.5 \%$ of cases).

- Codes of ethics very often deal with the topic of the offering and acceptance of gifts and sponsorship (in $75 \%$ of cases).

- Codes of ethics contain, on the whole, information on the handling of confidential information (in $72.5 \%$ of cases) and intellectual property protection (in $45 \%$ of cases).

- Almost two-thirds (62.5\%) of codes of ethics contain provisions on relations with stakeholders. This most frequently takes the form of a declaration of ethical commitments to employees (e.g. respectable behaviour towards them, tackling discrimination of all kinds, etc.), as well as to customers and suppliers. Surprisingly, commitments to the general public, public authorities, shareholders and investors are mentioned very rarely.

- Provisions dealing with conflicts of interest appear in $65 \%$ of the codes.

- Personal data protection is explicitly solved in $60 \%$ of the codes.

- Only $45 \%$ of codes were tailored in full to the organization - environment, industry.

- Ethical standards with regards to human resource management is directly dealt with in $37.5 \%$ of the codes, and only partially in $30 \%$ of the codes. 
- Less than one-third of the codes (32.5\%) provide categorical statements on the accuracy of accounting and reporting.

- Less than one-third of codes $(30 \%)$ contain an introductory or closing paragraph by the management in which they state their commitment to adhere to the provisions set out in the code of ethics.

- Only $25 \%$ of codes lay down sanctions for breaching the provisions of the code of ethics and criteria of evaluating.

- Only $20 \%$ of codes specifically mention that money laundering is not permitted.

- A surprisingly low number of company's present their vision and mission in their codes of ethics (they appear in only $10 \%$ of cases).

- The issue of lobbying only appears in codes of ethics in exceptional cases, namely in $7.5 \%$ of codes.

Table 1. Selected criteria for the assessment of codes of ethics

Code volume (in number of pages)

4 p., 8 p., 11 p., 20 p., 2 p., 20 p., 5 p., 4 p., 4 p., 3 p., 3 p., 3 p., 3 p., 3 p., 2 p., 3 p., 72 p., 40 p., 31 p., 20 p., 7 p., 4 p., 1 p., 7 p., 3 p., 12 p., 4 p., 4 p., 8 p., 11 p., 20 p., 2 p., 20 p., 5 p., 4 p., 4 p., 3 p., 3 p., 3 p., 3 p., 3 p., 2 p., 5 p., 3 p., 9 p., 1 p., 1, 5 p., 22 p., 3 p., 9 p., 6 p., 2 p., 13 p., 6 p.

\begin{tabular}{|l|c|c|c|}
\hline & In Full & Partly & Not at all \\
\hline Language comprehensibility & $95 \%$ & $5 \%$ & $0 \%$ \\
\hline Introductory/closing word/management commitment & $30 \%$ & $12.5 \%$ & $57.5 \%$ \\
\hline Tailored to the organization - environment, industry & $45 \%$ & $35 \%$ & $20 \%$ \\
\hline Company's behaviour to stakeholders & $45 \%$ & $30 \%$ & $25 \%$ \\
\hline Employees' behaviour towards the company & $77.5 \%$ & $10 \%$ & $12.5 \%$ \\
\hline Ethical standards in the sphere of HR management & $37.5 \%$ & $30 \%$ & $32.5 \%$ \\
\hline Company's vision and mission & $10 \%$ & $20 \%$ & $70 \%$ \\
\hline Corruption and bribery & $77.5 \%$ & $5 \%$ & $17.5 \%$ \\
\hline Adherence to regulations & $80 \%$ & $5 \%$ & $15 \%$ \\
\hline Equal approach to employees & $70 \%$ & $5 \%$ & $25 \%$ \\
\hline Confidential information & $72.5 \%$ & $10 \%$ & $17.5 \%$ \\
\hline Offering gifts, acceptance of gifts, sponsorship & $75 \%$ & $0 \%$ & $25 \%$ \\
\hline Conflict of interests and the resolution thereof & $65 \%$ & $10 \%$ & $25 \%$ \\
\hline Intellectual property & $45 \%$ & $7.5 \%$ & $47.5 \%$ \\
\hline Protection of company assets & $62.5 \%$ & $7.5 \%$ & $30 \%$ \\
\hline Personal data protection & $60 \%$ & $12.5 \%$ & $27.5 \%$ \\
\hline Control and sanctions (for breaches) & $25 \%$ & $10 \%$ & $65 \%$ \\
\hline Relationship to the environment & $65 \%$ & $7.5 \%$ & $27.5 \%$ \\
\hline Accuracy of accounting and reporting & $32.5 \%$ & $10 \%$ & $57.5 \%$ \\
\hline Money laundering ban & $20 \%$ & $0 \%$ & $80 \%$ \\
\hline Lobbying & $10 \%$ & $2.5 \%$ & $87.5 \%$ \\
\hline
\end{tabular}

Source: Internal research

\section{Main differences in codes of companies operating nationally or internationally:}

- Among those companies operating internationally, 92.6\% declare they adhere to the regulations, this number is significantly lower among those companies operating nationally, namely $53.8 \%$. However, in both cases, the companies do not go beyond the scope of the law in making such provisions.

- In companies operating internationally, the four most important issues in their codes of ethics are adherence to legal regulations (in $92.6 \%$ of cases), the behaviour of 
employees towards the company, corruption and bribery, and the offering and acceptance of gifts or sponsorship (in equal measure in $85.2 \%$ of cases).

- In companies operating nationally, the four most important issues in their codes of ethics are their relationship to the environment (in $69.2 \%$ of cases), the behaviour of employees towards the company, and corruption and bribery (in equal measure in $61 \%$ of cases), and adherence to regulations, the offering and acceptance of gifts and sponsorship, and they hide/ignore the issue of conflicts of interest (all 70.4\%).

- Lobbying, money laundering and sanctions for breaches of the code of ethics are three issues that are not widely covered by companies, irrespective of whether they operate nationally or internationally. The first two issues are not dealt with at all by companies operating nationally, and the third issue only by $7.7 \%$ of those companies. Among those companies operating internationally, lobbying is dealt with by $14.8 \%$ of companies, money laundering by $29.6 \%$, and sanctions by $33.3 \%$.

- The relationship with stakeholders is dealt with in $70 \%$ of the codes of ethics of companies operating internationally, and by only $46.2 \%$ of those operating nationally.

- In companies operating internationally, $77.8 \%$ include provisions for dealing with the protection of company assets and personal data in their codes of ethics, whereas this is only $30.8 \%$ among those companies operating nationally.

- The situation with regards to ethical standards in the field of human resource management is similar between the two groups. In companies operating internationally, this is $37 \%$, and in those companies operating nationally, $38.5 \%$.

\section{Discussion}

A comparative analysis of codes of ethics of companies operating in the CR shows that they mostly contain similar topics to those found in codes of ethics of foreign companies $[1,2,8,11,12,15,19,24]$. What they also share in common is the importance attached to the same issues, namely adherence to regulations, the behaviour of employees towards the company, corruption and bribery, the offering and acceptance of gifts, and sponsorship. Within this context, it is also becoming increasingly clear that the issues of environmental protection and relationships with stakeholders are coming more and more to the fore.

This contribution also deals with the question of whether differences exist in codes of ethics between those companies operating nationally or internationally, as determined in four previous Czech studies $[4,5,11,24]$. The results of the study presented in this contribution confirm the findings in the aforementioned studies, namely that substantial differences do still exist according to a company's scope of activity.

The efficacy of codes of ethics is affected by numerous factors, among others, by the means and purposes for which they are created, implemented and applied $[19,25,26]$. The content and form of a code of ethics actually significantly determines the future efficacy thereof. The results of the study presented in this contribution confirm that, in the case of the examined codes of ethics, the majority do not meet this condition at all, or at best, only partially. Similarly, foreign studies show that this also applies to foreign companies $[1,5,8,19]$. 


\section{Conclusion}

The main goal of the research was to determine by means of qualitative comparative analysis to what extent the contents of codes of ethics of companies operating in the Czech Republic meet key preconditions for efficacy. The results of the comparative analysis revealed that significant differences exist in terms of the content and the form of codes of ethics of companies operating in the CR. Significant differences were also confirmed to exists between those companies operating nationally and internationally. Despite the fact that several codes of ethics in the sample set were of high quality, the majority of the others showed shortcomings, namely they did not deal with key topics at all or only to a limited extent (see Table 1). In addition, a mechanism for checking adherence to the provisions in the codes of ethics was missing, as were sanctions for breaches of the codes of ethics. Most of the codes also failed to contain an explicit commitment from management to adhere to the code of ethics, which is a key precondition for efficacy. Furthermore, less than half of the codes seemed to be tailored to the real needs of the company and the industrial sector in which they operate. The protection of whistle-blowers was also very rarely declared.

As mentioned above, the efficacy of codes of ethics is affected by numerous factors, among others, by the means and purposes for which they are created, implemented and applied. These are the areas of interest that will form the focus of future research.

This paper was supported by the project Specific university research - No. SVV 202001 "Qualitative analysis of codes of ethics in several companies and subsequent creation and implementation of a code of ethics for a selected company."

\section{References}

1. Stevens, B. (2008). Corporate ethical codes: Effective instruments for influencing behavior. Journal of Business Ethics, 78(4), 601-609.

2. Erwin, P. M. (2011). Corporate codes of conduct: The effects of code content and quality on ethical performance. Journal of Business Ethics, 99(4), 535-548.

3. Kaptein, M. (2015). The effectiveness of ethics programs: The role of scope, composition, and sequence. Journal of Business Ethics, 132, 415-431.

4. Maňák, R., Nikolskaja, M., Tykva, T., Jones, M. (2017). Reflection of ethical principles in Czech codes of ethics. Innovation Management, Entrepreneurship and Sustainability, 553-565.

5. Berenbeim, R. (2000). Global Ethics. Executive Excellence, 17(5), 7.

6. Cleek, M. A., Leonard, S. L. (1998). Can Corporate Codes of Ethics Influence Behavior? Journal of Business Ethics, 17(6), 619-630.

7. Stevens, B. (1994). An analysis of corporate ethical code studies: Where do we go from here? Journal of Business Ethics, 13(1), 63-69.

8. Singh, J. B. (2006). A comparison of the contents of the codes of ethics of Canada's largest corporations in 1992 and 2003. Journal of Business Ethics, 64(1), 17-29.

9. Adams, J. S., Tashchian, A., Shore, T. H. (2001). Codes of Ethics as Signals for Ethical Behavior. Journal of Business Ethics, 29, 199-211.

10. Forster, M., Loughran, T., McDonald, B. (2009). Commonality in codes of ethics. Journal of Business Ethics, 90, 129-139. 
11. KPMG (2019). Pravidla hry - Analýza etických kodexů českých společností. Retrieved from : https://home.kpmg/content/dam/kpmg/cz/pdf/2019/kpmg-analyza-etickychkodexu-2019.pdf

12. Hoover, K., Pepper, M. (2015). How did they say that? Ethics statements and normative frameworks at best companies to work for. Journal of Business Ethics, 131(3), 605-617.

13. García-Sánchez, I. M., Frías Aceituno, J. V., Rodríguez-Domínguez, L. (2015). The ethical commitment of independent directors in different contexts of investor protection. Business Research Quarterly, 18(2), 81-94.

14. Benson, G. C. S. (1989). Codes of ethics. Journal of Business Ethics, 8(5), 305-319.

15. Schwartz, M. S. (2005). Universal moral values for corporate codes of ethics. Journal of Business Ethics, 59(1/2), 27-44.

16. Egels-Zandén, N., Lindholm, H. (2015). Do codes of conduct improve worker rights in supply chains? A study of Fair Wear Foundation. Journal of Cleaner Production, 107, 31-40.

17. Bartley, T., Egels-Zandén, N. (2015). Responsibility and neglect in global production networks: the uneven significance of codes of conduct in Indonesian factories. Global Networks, 15, 21-44.

18. Yu, X. (2008). Impacts of corporate code of conduct on labor standards: A case study of Reebok's athletic footwear supplier factory in China. Journal of Business Ethics, 81, 513-529.

19. Kaptein, M. (2004). Business Codes of Multinational Firms: What Do They Say? Journal of Business Ethics, 50(1), 13-31.

20. Remišova, A and Winkler, I. (2006). Comparison of Corporate Codes of Ethics in Slovak and Western German Firms. Economy Journal, 54(6), 597-610.

21. Džbánková (2003). Etické aspekty ekonomického prostředív ČR v procesu připojování $k E U$ - teoretický pohled a praktické zkušenosti. Marathon [online], 49(6), 3-19. Retrieved from : http://www.valencik.cz/marathon/03/mar030601.htm

22. Pricewaterhousecoopers (2016). Celosvětový pri̊zkum hospodářské kriminality 2016 zpráva za Českou republiku. Retrieved from : https://www.pwc.com/cz/cs/hospodarska-kriminalita/assets/pdf/global-economiccrime-survey-2016-cz.pdf

23. Caha, Z. (2017). Ethical Management in Companies in the Czech Republic and Ukraine - Comparison of the Presence of a Code of Ethics. In: J. Váchal et al. (Eds.), Innovative Economic Symposium 2017 (pp. 1-11). České Budějovice: EDP Sciences.

24. Pirozek, P., Komarkova, L. and Drasilova Safrova, A. (2018). Business Ethics in Subsidiaries of Multinational Companies in Countries in the Post-transition Economic Phase Using the Example of the Czech Republic. Journal for East European Management Studies. 23(2), 255-276.

25. Remišová (2015). Súčasné trendy podnikatel'skej etiky. Od tórie k praxi. Bratislava: Wolters Kluwer.

26. Caha and Urban (2017). A Code of Ethics as an Organizational Management Tool and its Use in the Czech Republic. Lüdenscheid: RAM-Verlag. 